\title{
PRZECIW MINISTERSTWU PRAWDY
}

Maciej Jabłoński, Przeciw muzykologii niewrażliwej,

Wydawnictwo Nauka i Innowacje, Poznań 2014.

Teksty, które Maciej Jabłoński zebrał w tomie Przeciw muzykologii niewrażliwej, jednoczy kilka dominujących tematów, obecnych w najważniejszych debatach toczonych w muzykologii i filozofii muzyki od roku 1985 do dziś. Nie tylko jednak tematy, również teoretyczne przesądzenia, budujące wywód autora, wyłożone zostały explicite i uczynione zagadnieniami centralnymi. Najważniejsze wydaje się następujące rozstrzygnięcie, dotyczące samego statusu muzyki.

Jabłoński konsekwentnie rozpatruje muzykę nie jako „obiektywnie” dany stan rzeczy czy system takich stanów, lecz jako fakt ludzkiej świadomości. Oznacza to, że wszelki akt muzyczny, włączając w to dzieło muzyczne $w$ rozumieniu europejskim, jest zawsze dany jako już zinterpretowany i znaczący, nie jest bowiem dostępny inaczej niż jako treść percepcji, przeżycia, doświadczenia i mówienia, które należy zawsze do usytuowanego podmiotu. Usytuowanego, a więc konkretnego, określonego przez swe miejsce w tym właśnie, a nie innym społeczeństwie, kulturze, światopoglądzie, sieci dyskursów itd., w sposób zawsze niepowtarzalny, i z konieczności mówiącego - także o muzyce - z pewnego dyskursywnego locus. Nie chodzi więc o podmiot zredukowany do czynności umysłowych apriorycznie umożliwiających doświadczenie, ani też o treść świadomości odsłoniętą w wyniku fenomenologicznego غ̇по $\grave{\eta}$, ale o historyczny podmiot filozofii pragmatystycznej i hermeneutycznej (oraz naszej codziennej egzystencji).

Teza ta właściwie nikogo nie powinna zaskakiwać: jest ona artykulacją, dla specyficznego pola muzyki, ogólnej koncepcji współczynnika humanistycznego, sformułowanej dawno już temu przez Floriana Znanieckiego 
i wyraża zasadniczą różnicę między „faktem” przyrodoznawstwa i „faktem" humanistyki, który okazuje się zawsze, już w punkcie wyjścia, interpretacją i wartością. Muzykologia ma jednak, od swego początku aż do dziś, skłonność, aby różnicę tę pomijać; więcej jeszcze - opcje teoretyczne oparte na owym pominięciu wydają się wielokrotnie w nauce o muzyce dominować. Muzykologowie szukają bowiem sojuszników w tego rodzaju koncepcjach, które usuwają muzykę poza świat historii: filozofii transcendentalnej (która pozwala definiować muzykę jako konstytuowaną przez uniwersalne, pozahistoryczne władze rozumu), filozofii fenomenologicznej (która pozwala widzieć dzieło muzyczne, jako czysty fenomen świadomości, oczyszczony, dzięki redukcji, z przygodnych, historycznych treści) czy neurofizjologii (która pozwala jeśli już nie idealistycznie, to przynajmniej biologicznie ugruntować uniwersalność muzyki poza światem kultury). Ta pierwsza i podstawowa decyzja teoretyczna Jabłońskiego stawia przed nim trzy fundamentalne zagadnienia, którym poświęcona jest duża część rozważań.

Po pierwsze zatem, Jabłoński konsekwentnie broni metodologicznie antynaturalistycznej wizji humanistyki, w tym muzykologii. Jeśli przedmiot muzykologii jest znaczeniem i wartością, to system procedur stworzonych w ramach "muzykologii pozytywistycznej” (w rozumieniu Josepha Kermana - choć Jabłoński jest oczywiście świadom karkołomności retorycznego skrótu, jakiego dokonał w tym momencie autor Musicology) jest względem tego przedmiotu nieadekwatny. Dokonuje bowiem przekształcenia muzyki w serię faktów o przyrodniczym charakterze, których struktura może być badana bez odniesienia do sensotwórczej i wartościującej aktywności podmiotu. Jako tego rodzaju „twarda” rzeczywistość, dzieła muzyczne mogą być opisywane i analizowane co do ich cech strukturalnych, które nagle jawią się jako obiektywnie dane w przedmiocie i czekające jedynie na odkrycie. Ustanawia to rodzaj odrębnej rzeczywistości muzycznej, klarownej i wygodnej w badaniu, i nie byłoby $\mathrm{w}$ tym nic zdrożnego, gdyby aktowi temu towarzyszyła świadomość konstrukcji, a więc zarazem świadomość możliwości konstrukcji alternatywnych. Muzykologia, która zechce się liczyć z tym, czym muzyka jest dla człowieka, będzie niestety wieloznaczna, mniej klarowna i trudniejsza, bo naznaczona wieczną niepewnością. Taką muzykologię zwolennicy muzykologii traktującej badania nad muzyką jako obiektywną analizę osobnej rzeczywistości muzycznej odrzucą jako „nienaukową". Nieraz tak zresztą określano każdą antynaturalistyczną humanistykę. Nie ma więc Jabłoński wyjścia - musi zaatakować ową „naukowość”. Czyni to, na przykład, włączając się do sporu Kofiego Agawu z Josephem Kermanem o status i znaczenie analizy. Tutaj jednak, z perspektywy czytel- 
nika, zadałbym innego rodzaju pytanie: co powinniśmy nazywać „nienaukowym" - przekroczenie norm dyskursu, przeniesionych zresztą z odmiennych dyscyplin i ufundowanych głównie na społecznym autorytecie przyrodoznawstwa, czy uporczywe ignorowanie podstawowych wymiarów ludzkiego doświadczenia muzyki w imię scjentystycznej czystości wywodu, odmawiającego zresztą filozoficznego przemyślenia własnych podstaw? Wbrew wymuszonemu przez historię dyskusji użyciu pojęć nie wydaje mi się, by Jabłoński bronił „nienaukowości”, a raczej atakuje on "naukowość”. Autor broni rzetelnej wierności specyfice przedmiotu wiedzy o muzyce, występując przeciw fake science, ograniczającej się do serii procedur niepoddanych filozoficznej refleksji.

Po drugie, jeśli muzyka jest czymś obdarzonym sensem i wartością, to jest czymś zawsze zarazem przekraczającym mowę, jako jej Inne, oraz czymś przez mówienie i pisanie określonym. W takiej perspektywie, muzykologia z jej decyzjami terminologicznymi i regułami dyskursu jest pewnym modus mówienia o muzyce. Jeśli pewien wywód odmawia rozpoznania własnego statusu jako sposobu mówienia, należy zapytać o niewypowiedziane, a stojące zanim założenia co do samego języka. Czyni to problem relacji języka i muzyki głównym chyba zagadnieniem książki Jabłońskiego. Celem autora jest konsekwentne przemyślenie konsekwencji dla muzykologii wszystkiego, czego dowiedzieliśmy dzięki filozofii języka: od Charlesa Sandersa Peirce'a i „późnego" Ludwiga Wittgensteina począwszy, poprzez koncepcje pragmatystyczne i antropologiczne badania nad językiem, po amerykański neopragmatyzm i francuski poststrukturalizm. Obraz siebie, jaki posiada część muzykologii, okazuje się bardzo trudny do utrzymania wobec wizji języka jako działania i znaczenia jako użycia - wizji zresztą, którą trudno byłoby dziś uważać za kontrowersyjną - i pozostaje zakorzeniony w bardzo trudnej do obrony koncepcji języka doskonale transparentnego oraz jednoznacznie mapowanego na niezależny odeń świat. Być może ze względów instrumentalnych takie trudne do obrony założenia co do języka musi przyjąć na przykład inżynier $\mathrm{w}$ trakcie pracy, ale przecież nie przyjmuje ich choćby fizyk-teoretyk. Konsekwencje uświadomienia sobie roli obserwatora i języka w konstruowaniu rzeczywistości doświadczenia nie okazały się jakoś destrukcyjne dla fizyki, nie ma więc powodu, by bać się ich w humanistyce. Inny jednak wątek wydaje mi się jeszcze istotniejszy w wywodach Jabłońskiego, to znaczy temat nieuchronnej nieadekwatności mowy o muzyce i doświadczenia muzyki, konstytuujący nie tylko zawsze obecne "przesunięcie" znaczenia muzyki w każdej o niej wypowiedzi, a więc zarazem swoistą semiotyczną szczelinę, w której wypowiedzi te się sytuują, ale przede 
wszystkim nadający nieuchronność metaforze jako podstawowemu medium mówienia nieadekwatnego: przypomnijmy znakomite analizy Nicholasa Cooka, odkrywające metaforyczne źródła wszelkiej muzycznej terminologii, znajdujące zresztą znakomite wsparcie $\mathrm{w}$ badaniach $\mathrm{z}$ kręgu kognitywnej antropologii muzyki.

Po trzecie, znaczenie i wartość, a razem z nimi interpretacja, stają w centrum wiedzy o muzyce. Nieadekwatność wszelkiej mowy o muzyce znajduje swe spełnienie zarówno w niezamykalności interpretacji, spowodowanej przez nieuchronną polisemię każdej metafory, ale też $\mathrm{w}$ nowym nadaniu znaczenia temu, co się interpretacji wymyka. Jeśli bowiem interpretacja jest niemożliwa do zamknięcia, to zarazem muzyka nie może zostać $w$ interpretacji wyczerpana, zawsze zachowując naddatek tego, co niewypowiedziane. Jabłoński ujmuje to poprzez rekurs do kategorii wzniosłości w jej Lyotardowskiej wykładni i bez wątpienia trudno o odwołanie lepsze. Wzniosłość jest ostatecznie, już w rozumieniu Kantowskim, właśnie doświadczeniem nieadekwatności.

Rodzi się z tego spójna wizja muzykologii filozoficznej - nie bez powodu wraca Jabłoński do pism Charlesa Seegera - sytuująca się w polu postdyscyplinarnym, z wszelkimi tego konsekwencjami. Przypomnijmy, że Kevin Korsyn użył określenia „postdyscyplinarność” dla określenia sytuacji o podwójnej charakterystyce, opisanej przez zamknięcie między „Wieżą Babel a Ministerstwem Prawdy": z jednej strony zatarcie granic między dyscyplinami, bynajmniej nie arbitralne, bo wynikające $\mathrm{z}$ odkrycia współzależności wszelkich wymiarów rzeczy ludzkich, i jednocześnie rozmnożenie się dyscyplin na wielość dyskursów o nieporównywalnych podstawach; z drugiej owo Ministerstwo Prawdy - układ stosunków władzy, wymogów instytucjonalnych itp., o oczekiwaniach dokładnie przeciwnych potrzebom dzisiejszej wiedzy. Jabłoński konsekwentnie bierze stronę Wieży Babel przeciw Ministerstwu Prawdy i pewnie nie raz usłyszy, że to, co proponuje, może i jest interesujące, ale nie należy już do muzykologii $w$ ścistym rozumieniu... (należy do filozofii, semiotyki, jakiejś metamuzykologii czy, nie daj Bóg, kulturoznawstwa). Taka lektura byłaby dla książki Jabłońskiego zapewne największym zagrożeniem, mogłaby bowiem zneutralizować jej krytyczne żądło poprzez usunięcie z pola tego, z czym koniecznie trzeba się zmierzyć. Ministerstwo Prawdy będzie jednak próbować.

Tocząc swoje pełne zaangażowania i starannie przemyślane polemiki, na przykład z koncepcją interpretacji integralnej proponowaną przez Mieczysława Tomaszewskiego, autor Przeciw muzykologii niewrażliwej szuka sprzymierzeńców. Znajduje ich w amerykańskiej Nowej Muzykologii, w filozofii 
języka i filozofii muzyki, wśród antropologów kulturowych, językoznawców, literaturoznawców, myślicieli postmodernistycznych i innych. Czasem są to sojusze taktyczne, którym nie można do końca wierzyć. Niektóre deklaracje - na przykład obrony postmodernizmu - mniej mają ostatecznie wspólnego z poglądami autora niż z budowaniem polemicznej retoryki, w słusznym zapewne przekonaniu, że polskiej wiedzy o muzyce potrzebny jest wstrząs. Maciej Jabłoński napisał książkę, która wstrząsu takiego może dokonać - uargumentowaną, prowokacyjną, ale przemyślaną w swych tezach, odważną, pełną osobistego przekonania, lecz przede wszystkim stawiającą kluczowe pytania i na nowo sytuującą muzykologię w całościowym polu humanistyki. Jest to nie tylko wyzwanie dla muzykologów, którzy chcieliby myśleć o muzyce $\mathrm{w}$ oderwaniu od reszty humanistyki. W równie wielkim, jeśli nie większym stopniu jest to wyzwanie dla innych humanistów, którzy chcieliby w naukach o kulturze zignorować muzykologię. Już się nie da: w krajach anglojęzycznych muzykologia przez ostatnich trzydzieści lat stała się dyscypliną, wobec której żaden humanista nie może przejść obojętnie. Można mieć nadzieję, że książka Jabłońskiego rozpoczyna zmianę w tym samym kierunku w świecie humanistyki polskiej. 